\title{
Differential Viability of Eight Human Blood Mononuclear Cell Subpopulations After Plasma Treatment
}

\author{
Sander Bekeschus, $, 1,2, \star$ Julia Kolata, ${ }^{2}$ Anne Müller, ${ }^{1}$ Axel Kramer, ${ }^{3}$ Klaus-Dieter \\ Weltmann, ${ }^{1}$ Barbara Bröker ${ }^{2} \&$ Kai Masur ${ }^{1}$
}

${ }^{1}$ ZIK plasmatis at Leibniz Institute for Plasma Science and Technology, Greifswald, Germany; ${ }^{2}$ Institute of Immunology and Transfusion Medicine, Department of Immunology, and ${ }^{3}$ Institute of Hygiene and Environmental Medicine, University of Greifswald, Greifswald, Germany

*Address all correspondence to Sander Bekeschus, ZIK plasmatis at Leibniz Institute for Plasma Science and Technology, Felix-Hausdorff-Str. 2, 17489, Greifswald, Germany; sander.bekeschus@inp-greifswald.de

\begin{abstract}
In plasma medicine, basic and translational research aids in future application of cold plasma sources in human diseases or disorders (e.g., chronic wounds). While most work has focussed on the interaction of skin cells with plasma, immune system cells have only been marginally examined. Their role is of major importance because they fulfill key regulatory parts in immune responses and modulate inflammation in all types of tissues. This work systematically investigates eight different subpopulations (monocytes and $\mathrm{CD} 4^{+}, \mathrm{CD} 8^{+}, \mathrm{B}$, $\mathrm{NK}, \mathrm{NKT}, \mathrm{T}_{\mathrm{H}} 17$, and $\gamma \delta \mathrm{T}$ cells) of human peripheral blood mononuclear cells with regard to viability after 5,20 , or $60 \mathrm{~s}$ of plasma treatment. Twenty-four hours after exposure, viability differed between populations ( $23.1 \% \mathrm{CD}^{+}$versus $41.9 \% \gamma \delta \mathrm{T}$ cells after $60 \mathrm{~s}$ of exposure) as revealed by flow cytometry. Cellular activation before plasma treatment increased survival in all subpopulations tested $\left(26.8 \%\right.$ in nonstimulated versus $50.0 \%$ in stimulated $\mathrm{CD} 8^{+} \mathrm{T}$ cells after $60 \mathrm{~s}$ of exposure). All lymphocyte subpopulations showed significantly $(P<0.05)$ lower survival rates compared to monocytes $(35.9 \%$ for B cells versus $82.5 \%$ for monocytes after $60 \mathrm{~s}$ of exposure) but not compared to each other, hallmarking two intrinsically different coping types of cells regarding plasma cytotoxicity.
\end{abstract}

KEY WORDS: plasma medicine, cold atmospheric pressure plasma, human blood cells, reactive oxygen and nitrogen species, oxidative stress

\section{INTRODUCTION}

Plasma medicine has introduced exciting new fields in biology, biotechnology, and clinical medicine in recent years..$^{1,2}$ One such field is the treatment of human tissues, in which beneficial antimicrobial and tissue-stimulating effects are combined. ${ }^{3,4}$ Connective tissue cells such as fibroblasts or keratinocytes as well as tumor cell lines have been the subject of numerous cold plasma studies thus far. ${ }^{5-10}$ Cold plasma is thought to mediate its effects on cells mainly via reactive oxygen and nitrogen species (RONS). ${ }^{11,12}$ Treatment time-dependent RONS induce oxidative stress and finally apoptosis or cell death in eukaryotic or prokaryotic cells, respectively. ${ }^{13,14}$ Current debate surrounds which exact species are responsible, but hydrogen peroxide seems to play a central role in plasma-induced oxidative stress. ${ }^{15-18}$ Plasma treatment of immune cells has received little 
attention despite their importance and regulatory role in different diseases and tissues, as well as in overall health. ${ }^{19-22}$ We previously showed that plasma induces apoptosis in human peripheral blood mononuclear cells (PBMCs). ${ }^{23}$ In this work, we systematically characterized the viability of eight PBMC subpopulations after plasma treatment. We utilized an atmospheric pressure argon plasma jet (kINPen 09), which is similar in construction to the accredited kINPen MED that has shown beneficial effects in applications on the skin in which immune cells are also present. ${ }^{24,25}$ Immune cells are quiescent in blood while during migration to or at inflammatory sites, e.g. wounds, they become activated. We mimicked this condition by stimulating PBMCs with a potent mitogen and compared survival rates to those of nonstimulated cells. All cell populations were characterized by multicolor flow cytometry. The investigated cell types are important players in wound healing or regulation of inflammation. Monocytes/macrophages and natural killer T (NKT) cells contribute to cutaneous wound repair. Excessive inflammation in psoriasis is driven by $T$ helper $\left(\mathrm{T}_{\mathrm{H}}\right)$ cells such as $\mathrm{T}_{\mathrm{H}} 17$ cells, and $\gamma \delta \mathrm{T}$ cells have a unique role in homeostatic processes of mucosal surfaces and in wound healing. ${ }^{20,26-29}$ Moreover, the cytotoxicity of NK cells and $\mathrm{CD} 8^{+}$cells is important in tumor surveillance and antiviral activity, whereas $\mathrm{CD} 4^{+} \mathrm{T}$ cells and $\mathrm{B}$ cells are central in eliciting adaptive immune responses. ${ }^{21,30}$ Despite these unique functions, we hypothesized that different lymphocyte subpopulations cope similarly with plasma cytotoxicity due to hematological lineage relationships from a common lymphoid progenitor, and that survival of lymphocytes and monocytes may differ because the latter derive from a common myeloid progenitor. Together, this work explored the cellular susceptibility of different immune cell types and cellular activation states after cold plasma treatment.

\section{MATERIALS AND METHODS}

\section{A. Cell Isolation}

Upon donation at the blood bank (University Medicine of Greifswald, Germany), healthy blood donors gave written and informed consent about anonymous usage of blood for research purposes in the case that the donation is not suitable for clinical application. Human PBMCs were enriched by density gradient centrifugation with lymphocyte separation medium (PAA). After isolation, cells were suspended at $1 \times 10^{6} / \mathrm{ml}$ in medium (RPMI 1640 without phenol red; PAA) containing 10\% fetal bovine serum (Biochrom) and $1 \%$ glutamine/penicillin/streptomycin (PAA). Cells were seeded at $1 \mathrm{ml}$ per well in 24-well plates (Costar) overnight either with or without $500 \mathrm{ng} / \mathrm{ml}$ phytohemagglutinin (PHA; Biochrom) prior to plasma exposure.

\section{B. Plasma Source and Treatment}

The kINPen 09 (neoplas $\mathrm{GmbH}$ ) atmospheric pressure plasma jet was utilized. An argon plasma was used as previously described with an effluent length of $1.5 \mathrm{~cm}$ and operated at a gas flow of 3 standard liters per minute. ${ }^{24}$ Gas flow was controlled by a mass flow 
controller (MKS Instruments). Cell culture medium was exchanged prior to treatment. Reproducible direct plasma treatment was guaranteed using a programmable, computerdriven $x y z$ table (neoplasm $\mathrm{GmbH}$ ) hovering the jet above the center of each well for the indicated time period at a constant height as previously described. ${ }^{23}$ Three different treatments times were applied to cells $(5 \mathrm{~s}, 20 \mathrm{~s}, 60 \mathrm{~s})$ in 2-4 replicates for each data set. To exclude effects of the carrier gas alone, argon gas controls were carried out for each experiment and always resembled untreated control values (data not shown).

\section{Flow Cytometry}

Data were collected by flow cytometry (Gallios; Beckman-Coulter). Twenty-four hours after plasma treatment, cells were collected into $12 \times 75 \mathrm{~mm}$ polypropylene tubes (Sarstedt), washed with phosphate-buffered saline, and incubated for $10 \mathrm{~min}$ with $1 \mu \mathrm{g} /$ $\mathrm{ml}$ Cohn II (Sigma) in staining buffer (Miltenyi). For discrimination of PBMC subpopulations, antibodies directed against the following antigens were used: $\gamma \delta$ TCR PE (Beckman-Coulter); CD4 PE-CF 594 (Becton-Dickinson); $\alpha \beta$ CD3 PerCP Cy5.5, $\alpha \beta$ CD3 Alexa-Fluor 700, CD4 APC, CD4 APC-Cy7, CD14 PerCP Cy5.5, CD14 PE-Cy7, CD56 APC-Cy7, CD161 APC, and CD196 PE (Biolegend); and CD4 APC, CD8 PerCP, CD14 FITC, and CD19 PE (Miltenyi). Staining in staining buffer took place for $30 \mathrm{~min}$ at room temperature in the dark. To further assess viability, cells were then washed and stained with Annexin V FITC (Biolegend) or Annexin V PE-Cy7 (eBioscience) and $1 \mu \mathrm{M}$ 4',6-diamidino-2-phenylindole (DAPI; VWR) in Annexin V binding buffer (Biolegend). DAPI only binds to DNA of cells with compromised cell membranes. After exclusion of doublets and debris, each population was discriminated as follows: monocytes $\left(\mathrm{CD} 14^{+}\right)$, $\mathrm{B}$ cells $\left(\mathrm{CD} 3^{-}, \mathrm{CD} 14^{-}, \mathrm{CD} 19^{+}\right)$, NK cells $\left(\mathrm{CD} 3^{-}, \mathrm{CD}^{-} 4^{-}, \mathrm{CD}^{+} 6^{+}\right), \mathrm{T}^{2}$ helper cells $\left(\mathrm{CD} 14^{-}\right.$, $\left.\mathrm{CD}^{+}, \mathrm{CD}^{+}\right)$, cytotoxic $\mathrm{T}$ cells $\left(\mathrm{CD} 14^{-}, \mathrm{CD}^{+}, \mathrm{CD}^{+}\right), \mathrm{NKT}$ cells $\left(\mathrm{CD} 14^{-}, \mathrm{CD}^{+}, \mathrm{CD}^{+} 6^{+}\right)$, $\mathrm{T}_{\mathrm{H}} 17$ cells $\left(\mathrm{CD} 14^{-}, \mathrm{CD}^{+}, \mathrm{CD}^{+}, \mathrm{CD} 161^{+}, \mathrm{CD} 196^{+}\right)$, and $\gamma \delta \mathrm{T}$ cells $\left(\alpha \beta \mathrm{CD}^{-}, \gamma \delta \mathrm{TCR}^{+}\right)$. Viability was determined as the percentage of each cell population being negative for Annexin V and DAPI. For assessment of cellular oxidation by plasma, PBMCs were incubated with $2 \mu \mathrm{M}$ 2', 7'-dichlorodihydrofluorescein diacetate $\left(\mathrm{H}_{2} \mathrm{DCF}-\mathrm{DA}\right.$; Sigma) for 30 min at $37^{\circ} \mathrm{C}$ with $5 \% \mathrm{CO}_{2}$. After washing, cells were seeded in 24-well plates and plasma was treated as described above. Cells were then collected into $12 \times 75 \mathrm{~mm}$ polypropylene tubes and washed, and green fluorescence of the probe was measured by flow cytometry using a 525/40 nm emission filter. The median fluorescence intensity of a DAPI ${ }^{-}$PBMC $^{-}$ gate was calculated per sample.

\section{Statistical Analysis}

Data analysis was performed using Kaluza 1.2. (Beckman-Coulter) and Excel 2010 (Microsoft) software. Graphing and statistical analysis were carried out using Prism 6.03 software (GraphPad Software). Each dot represents the mean of 2-4 replicates of one treatment time length of cells of one donor. Bars represent the mean. Statistical significance within one group was calculated by nonmatched two-way analysis of vari- 
ance (ANOVA) comparing row means followed by Bonferroni post-testing comparing to the untreated control. Statistical significance between nonstimulated and stimulated cells of one subpopulation was calculated by nonmatched two-way ANOVA comparing row means between all columns followed by Holm-Sidak post-testing. Statistical significance between two different subpopulations was calculated by nonmatched twoway ANOVA comparing main column effects followed by Sidak post-testing. For redox changes, column means were compared with one-way ANOVA followed by Dunnett post-testing comparisons to untreated controls. Significance levels are indicated as follows: ${ }^{*} \alpha=0.05,{ }^{* *} \alpha=0.01$, and ${ }^{* * *} \alpha=0.001$.

\section{RESULTS AND DISCUSSION}

\section{A. Survival of PBMC Subpopulations After Plasma Treatment}

It is known that oxidative stress induces apoptosis as it tips the balance between intracellular oxidants and antioxidants. ${ }^{31}$ Plasma induces oxidative stress via generation of RONS. $\mathrm{H}_{2}$ DCF-DA is an indicator of intracellular oxidation and its fluorescence increased in PBMCs exposed to plasma (Fig. 1). Oxidative stress may at least in part be responsible for the apoptotic effects of plasma that we have previously seen in human PBMCs. ${ }^{23}$ In this work, we investigated survival rates of eight PBMC subpopulations after plasma exposure. This was done according to the gating strategies depicted in Fig. 2. Primary cells are not adapted to culture conditions as cell lines are and residual occurrence of dead cells in nontreated controls is common and donor dependent. Due to apoptosis induction in all cell types, viability decreased in a treatment time- dependent manner (Fig. 3A). In all cell types but monocytes, survival after $60 \mathrm{~s}$ of plasma treatment differed significantly compared to corresponding controls. Monocytes were the most robust population in plasma-treated PBMCs ( $82 \%$ survival for $60 \mathrm{~s}$ of plasma). Apoptosis induction in all other cell types was high (1.1\%-41.9\% survival) after $60 \mathrm{~s}$ of plasma exposure. This includes $\mathrm{T}_{\mathrm{H}} 17$ cells, which are associated with psoriasis and could be a potential target in plasma medicine. ${ }^{32} \gamma \delta \mathrm{T}$ cells displayed the lowest lymphocyte sensitivity and this could possibly be due to their physiological location in the skin and gut, both of which are environments that are enriched for oxidative stressors. ${ }^{20}$ It was previously reported that cytotoxic $\mathrm{T}$ cells survive dielectric barrier discharge plasma treatment better than $\mathrm{T}$ helper cells in rats. ${ }^{33} \mathrm{We}$ did not find this difference in human cells, as $\mathrm{CD}^{+}$and $\mathrm{CD} 8^{+} \mathrm{T}$ cell viability neither differed significantly for nonstimulated treatment regime nor for the PHA-stimulated treatment regime (Fig. 3, Table 2).

\section{B. Mitogenic Stimulation Alters Survival Rates of Cells After Plasma Treat- ment}

Peripheral blood cells are usually quiescent, whereas immune cells in inflamed tissues are stimulated by extravasation and local cytokine and chemokine gradients. ${ }^{34}$ To mimic activation and compare cell survival to nonstimulated cells, we treated PBMCs 


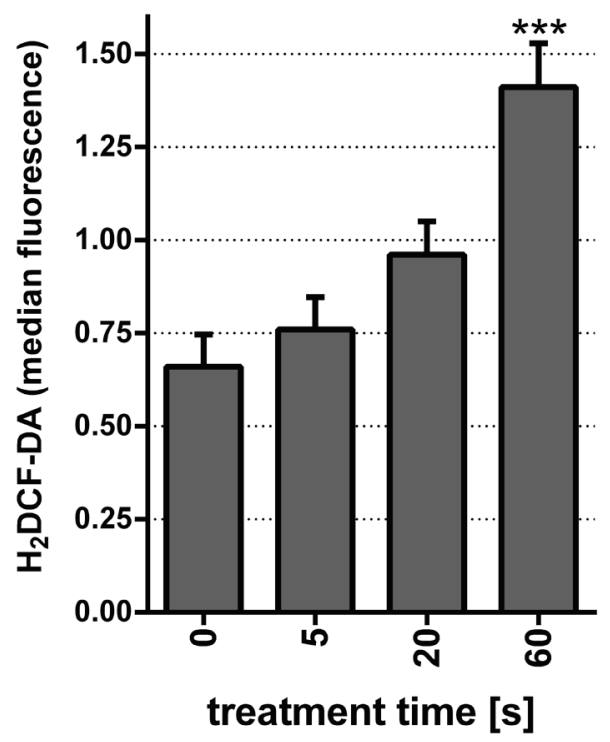

FIG. 1: Intracellular oxidation of plasma-treated PBMCs. After plasma exposure, PBMCs were washed and intracellular $\mathrm{H}_{2}$ DCF-DA fluorescence was measured by flow cytometry. The median fluorescence intensity was calculated per sample and increased with the length of treatment time. Compared to controls, intensity differed significantly $\left({ }^{* *} P<0.001\right)$ for $60 \mathrm{~s}$ of plasma treatment. Data are presented as the mean \pm standard error $(n=4)$.

with PHA overnight prior to plasma exposure. PHA is a herbal lectin and mitogen that activates $T$ cells in a nonantigen-specific manner. ${ }^{35}$ For $60 \mathrm{~s}$ of plasma treatment, comparison of the survival rates between nonstimulated and stimulated cells revealed a survival advantage for stimulated cells of all types investigated (Table 1). This might be due to an increased intracellular production of reactive oxygen species as found in stimulated $\mathrm{T}$ lymphocytes in patients ${ }^{36}$ and a subsequent upregulation of enzymes of the antioxidant defense system providing a better overall protection against plasmagenerated RONS. Another mechanism might be the induction of antiapoptotic pathways through PHA in lymphocytes and its initiated cytokine. ${ }^{37}$ Activation of lymphocytes and cytokines induces antiapoptotic responses, ${ }^{38}$ which would increase cellular survival after plasma exposure. In general, substantial amounts of interleukin (IL)-2, IL-6, IL-8, tumor necrosis factor- $\alpha$, and interferon- $\gamma$ were detectable in supernatants of PBMCs cultured with PHA (data not shown). It is likely that this proinflammatory milieu rendered all cell types investigated more resistant to plasma cytotoxicity. For example, IL-2 enhances T cell survival and proliferation. ${ }^{39}$ Nevertheless and expectedly, PHA addition also markedly decreased viability in controls in NKT, $\mathrm{CD}^{+} \mathrm{T}^{+}$ and $\mathrm{CD}^{+} \mathrm{T}$ cells, and significantly $(P=0.004)$ in $\mathrm{T}_{\mathrm{H}} 17$ cells, probably via activationinduced cell death. ${ }^{40}$ PHA addition did not significantly affect monocyte survival rates for any plasma treatment time. For most cell types investigated, our results show a 

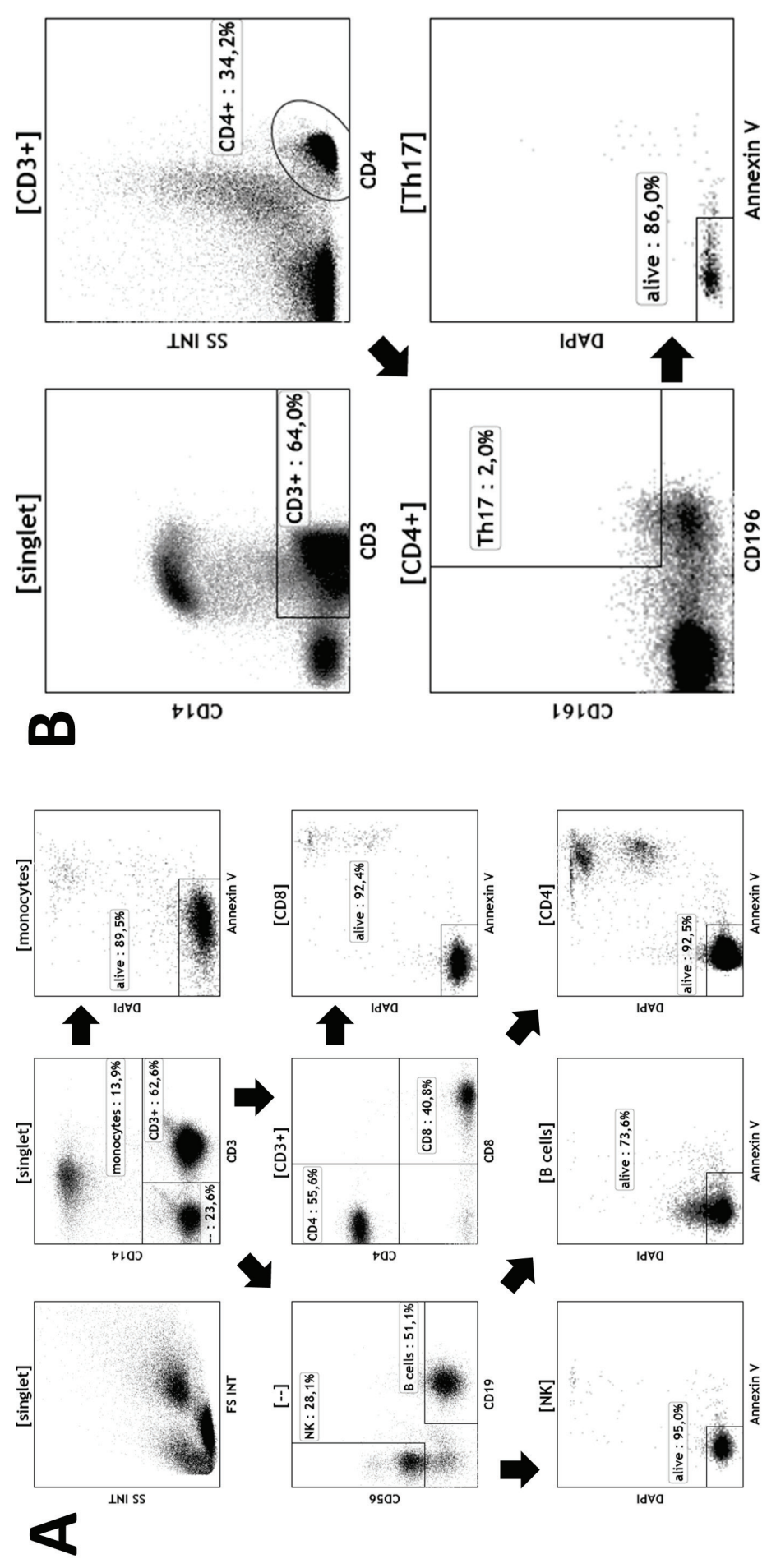

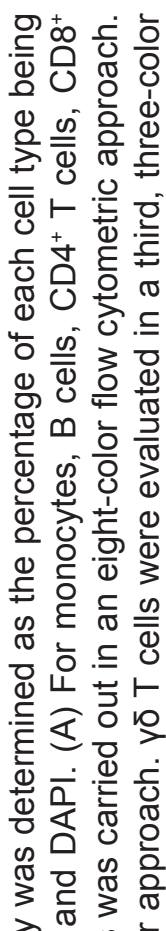

긍> 을 흥

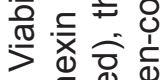

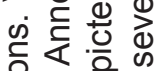

坖就

을

응워

윽 要

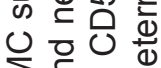

웡

즌

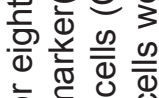

ㅎํㅇํㅇ

幽은 녿

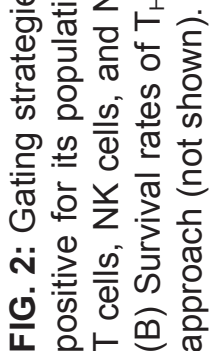



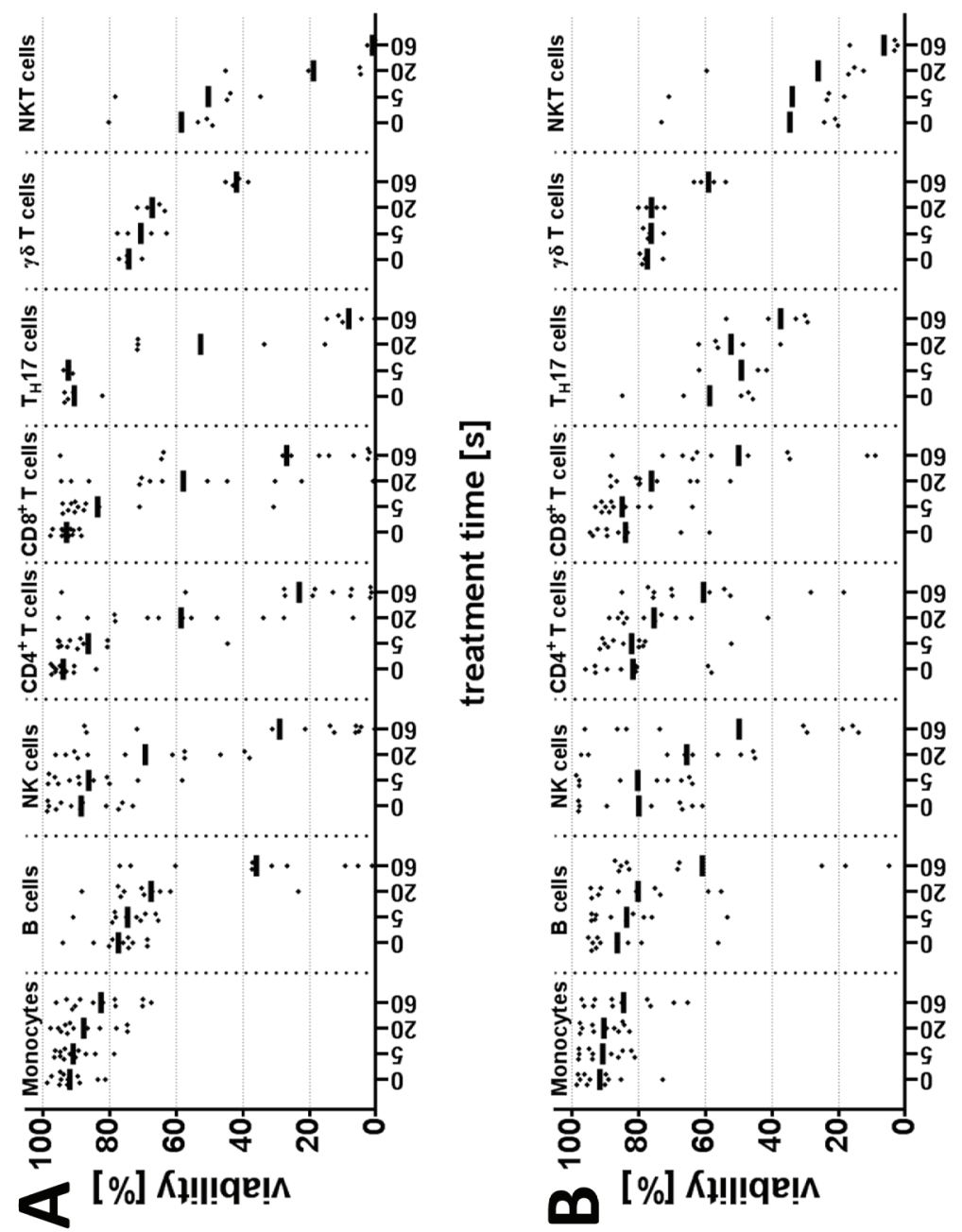

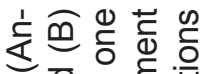

过

$\frac{\pi}{5} \frac{\infty}{\overline{0}} \stackrel{0}{=}$

空 है

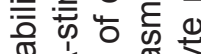

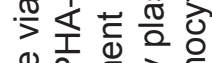

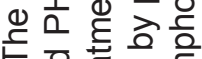

1 व

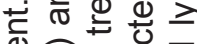

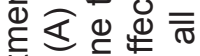

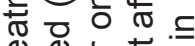

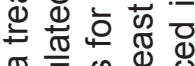

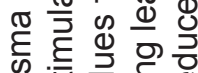

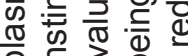

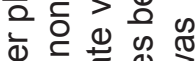

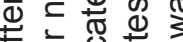

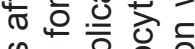

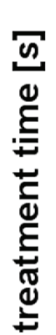

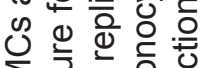

ए $\sum_{0}$ के ह

a 잉

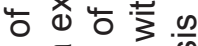

들 둥 ?

क 0 ब

$\frac{\pi}{5} \frac{\pi}{0} \varepsilon$ 은

$\varepsilon$

is

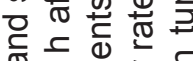

ब。

只完

응 웡 웡

뜰 등

응 항 के के

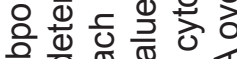

क 음

ᄃ

$\Phi$

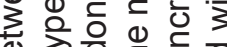

ब응

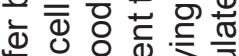

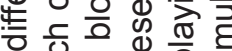

क ष

ब $ه$

त्र

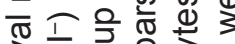

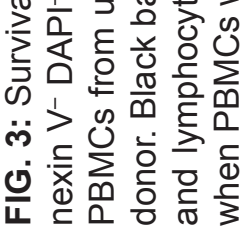




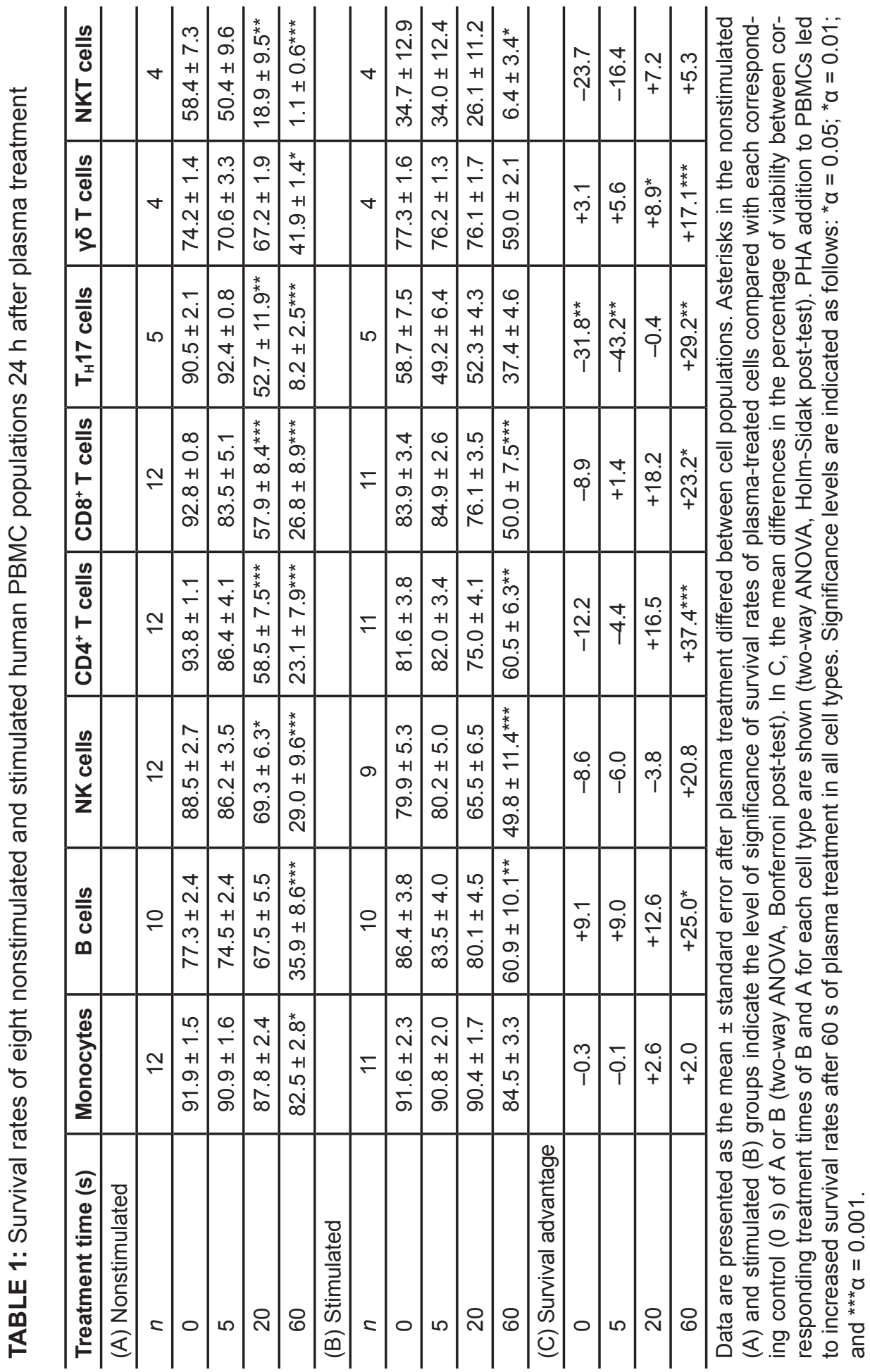


high variability between blood donors. Because the usage of blood was anonymous, differences between donors cannot be explained.

\section{Distinguishable Monocytes and Lymphocytes Susceptibility Toward Plasma}

While differences within each subpopulation for any plasma treatment time or stimulation were outlined (Table 1), we further sought to compare subpopulations. Regardless of PHA addition, monocyte survival significantly differed from survival of any other subpopulations investigated (Table 2). This clearly distinguishes this phagocytic cell type from all other lymphocyte cell types with regard to withstanding plasma cytotoxicity. This could be due to differences in proapoptotic and antiapoptotic signaling events as a comparison between a lymphocyte and monocyte cell lines suggested. ${ }^{41}$ Another possibility may be a stronger antioxidative defense system against plasma-induced oxidative stress, which under physiological conditions protects these phagocytes against self-produced ROS during oxidative burst. ${ }^{42}$ Furthermore, there was no significant difference between the viability rates of any two lymphocyte subpopulations (B cells, NK cells, CD4 ${ }^{+}$T cells, CD8 ${ }^{+}$ $\mathrm{T}$ cells, and $\gamma \delta \mathrm{T}$ cells) after plasma treatment, irrespective of PHA activation. The similar lymphoid cell survival rate on the one hand and strikingly different survival of a myeloid cell type (monocytes) on the other suggest that cellular susceptibility to plasma is at least partially due to progenitor descendance. As group means were compared (Table 2), $\mathrm{T}_{\mathrm{H}} 17$ and NKT cells are not listed due to their low viability in controls.

\section{CONCLUSION}

Cells of the immune system are present and relevant in many potential applications of cold atmospheric plasma. We investigated eight PBMC populations with regard to viability after plasma exposure. Monocytes showed only a mild decrease in viability, whereas all seven lymphocyte populations were strongly affected by plasma treatment. Overall survival rates of monocytes were significantly different from all lymphocyte cell types, whereas viability rates of any two lymphocyte subpopulations did not differ significantly between each other. This finding underlined substantial differences between phagocytes and lymphocytes regarding their intrinsic resistance toward cold plasma-induced oxidative stress or cytotoxicity. To mimic activation, we also stimulated PBMCs with PHA prior to exposure. The direct comparison of survival rates between nonstimulated and stimulated cells revealed a survival advantage of the latter. Whether this was caused by PHA-mediated and increased antioxidative capacity, antiapoptotic signaling events, or cytokine responses of stimulated cells remains a topic of future investigations.

\section{ACKNOWLEDGMENTS}

The authors thank Dr. Andreas Greinacher (Head of the Department of Transfusion Medicine, University of Greifswald, Germany) for allocating buffy coats. 
TABLE 2: Statistical differences between survival rates of six plasma-treated PBMC subpopulations

\begin{tabular}{|c|c|c|}
\hline Comparison & Nonstimulated & Stimulated \\
\hline Monocytes versus $\mathrm{CD}^{+} \mathrm{T}$ cells & $P<0.001^{* * *}$ & $P<0.001^{* \star}$ \\
\hline Monocytes versus $\mathrm{CD}^{+} \mathrm{T}$ cells & $P<0.001^{* * *}$ & $P<0.001^{* * *}$ \\
\hline Monocytes versus NK cells & $P<0.001^{* * *}$ & $P<0.001^{\text {*** }}$ \\
\hline Monocytes versus $B$ cells & $P<0.001^{* * *}$ & $P=0.033^{*}$ \\
\hline Monocytes versus $ү \delta$ T cells & $P<0.001^{* * *}$ & $P=0.009^{\star \star}$ \\
\hline $\mathrm{CD}^{+} \mathrm{T}$ cells versus $\mathrm{CD} 8^{+} \mathrm{T}$ cells & n.s. & n.s. \\
\hline $\mathrm{CD}^{+} \mathrm{T}$ cells versus NK cells & n.s. & n.s. \\
\hline $\mathrm{CD}^{+} \mathrm{T}$ cells versus $\mathrm{B}$ cells & n.s. & n.s. \\
\hline $\mathrm{CD}^{+}{ }^{+} \mathrm{T}$ cells versus $\gamma \delta \mathrm{T}$ cells & n.s. & n.s. \\
\hline $\mathrm{CD}^{+} \mathrm{T}$ cells versus NK cells & n.s. & n.s. \\
\hline $\mathrm{CD}^{+} \mathrm{T}$ cells versus $\mathrm{B}$ cells & n.s. & n.s. \\
\hline $\mathrm{CD}^{+} \mathrm{T}$ cells versus $\gamma \delta \mathrm{T}$ cells & n.s. & n.s. \\
\hline NK cells versus $B$ cells & n.s. & n.s. \\
\hline NK cells versus $ү \delta$ T cells & n.s. & n.s. \\
\hline B cells versus $ү \delta$ T cells & n.s. & n.s. \\
\hline
\end{tabular}

Regardless of stimulation, survival rates of monocytes always differed significantly compared to those of five lymphocytic subpopulations, whereas comparison of survival between each of five lymphocyte populations did not differ. Due to low baseline survival, comparison of $T_{H} 17$ cells and NKT cells is not shown. Calculation was done using nonmatched two-way ANOVA comparing main column effects of all treatments for each population followed by Sidak posttesting. Significance levels are indicated as follows: ${ }^{*} \alpha=0.05 ;{ }^{* *} \alpha=0.01 ;{ }^{* * *} \alpha=0.001$; or n.s., nonsignificant.

\section{ROLE OF FUNDING SOURCE}

This work was realized within the framework of the ZIK plasmatis multidisciplinary research center, which is funded by the German Federal Ministry of Education and Research (grant 03Z2DN11).

\section{REFERENCES}

1. Vandamme M, Robert E, Dozias S, Sobilo J, Lerondel S, Le Pape A, Pouvesle JM. Response of human glioma U87 xenografted on mice to non thermal plasma treatment. Plasma Med. 2011;1:27-43.

2. Graves DB. The emerging role of reactive oxygen and nitrogen species in redox biology and some implications for plasma applications to medicine and biology. J Phys D Appl Phys. 2012;45:263001-42.

3. Matthes R, Bekeschus S, Bender C, Koban I, Hübner NO, Kramer A. Pilot-study on the influence of carrier gas and plasma application (open resp. delimited) modifications on physi- 
cal plasma and its antimicrobial effect against Pseudomonas aeruginosa and Staphylococcus aureus. GMS Krankenhaushygiene Interdisziplinar. 2012;7:1-7.

4. Laroussi M. Low-temperature plasmas for medicine? IEEE Trans Plasma Sci. 2009;37:714-25.

5. Schmidt A1, Wende K, Bekeschus S, Bundscherer L, Barton A, Ottmüller K, Weltmann KD, Masur K. Non-thermal plasma treatment is associated with changes in transcriptome of human epithelial skin cells. Free Radical Res. 2013;47:577-92.

6. Lopes BB, Kraft MBdPL, Rehder J, Batista FRX, Puzzi MB. The interactions between non-thermal atmospheric pressure plasma and ex-vivo dermal fibroblasts. Procedia Eng. 2013;59:92-100.

7. Partecke LI1, Evert K, Haugk J, Doering F, Normann L, Diedrich S, Weiss FU, Evert M, Huebner NO, Guenther C, Heidecke CD, Kramer A, Bussiahn R, Weltmann KD, Pati O, Bender C, von Bernstorff W. Tissue tolerable plasma (TTP) induces apoptosis in pancreatic cancer cells in vitro and in vivo. BMC Cancer. 2012;12:473-82.

8. Sensenig R1, Kalghatgi S, Cerchar E, Fridman G, Shereshevsky A, Torabi B, Arjunan KP, Podolsky E, Fridman A, Friedman G, Azizkhan-Clifford J, Brooks AD. Non-thermal plasma induces apoptosis in melanoma cells via production of intracellular reactive oxygen species. Ann Biomed Eng. 2011;39:674-87.

9. Georgescu N, Lupu AR. Tumoral and normal cells treatment with high-voltage pulsed cold atmospheric plasma jets. IEEE Trans Plasma Sci. 2010;38:1949-55.

10. Lupu AR, Georgescu N, Calugaru A, Cremer L, Szegli G, Kerek F. The effects of cold atmospheric plasma jets on B16 and COLO320 tumoral cells. Roum Arch Microbiol Immunol. 2009;68:136-44.

11. Stoffels E, Kieft IE, Sladek REJ, van den Bedem LJM, van der Laan EP, Steinbuch M. Plasma needle for in vivo medical treatment: recent developments and perspectives. Plasma Sources Sci Technol. 2006;15:S169.

12. Wende K, Landsberg K, Lindequist U, Weltmann KD, von Woedtke T. Distinctive activity of a nonthermal atmospheric-pressure plasma jet on eukaryotic and prokaryotic cells in a cocultivation approach of keratinocytes and microorganisms. IEEE Trans Plasma Sci. 2010;38:2479-85.

13. Arjunan KP, Friedman G, Fridman A, Clyne AM. Non-thermal dielectric barrier discharge plasma induces angiogenesis through reactive oxygen species. J R Soc Interface. 2012;9:147-57.

14. Laroussi M, Dobbs FC. Effects of nonequilibrium plasmas on eukaryotic cells [final report of AFOSR Grant FA9550-1-0004]. Norfolk (VA): Old Dominion University Department of Electrical and Computer Engineering; 2009.

15. Winter J, Wende K, Masur K, Iseni S, Dünnbier M, Hammer MU, Tresp H, Weltmann KD, Reuter S. Feed gas humidity: a vital parameter affecting a cold atmospheric-pressure plasma jet and plasma-treated human skin cells. J Phys D Appl Phys. 2013;46:295401.

16. Liu F, Sun P, Bai N, Tian Y, Zhou H, Wei S, Zhou Y, Zhang J, Zhu W, Becker K, Fang J. Inactivation of bacteria in an aqueous environment by a direct-current, cold-atmosphericpressure air plasma microjet. Plasma Processes Polymers. 2010;7:231-6.

17. Kalghatgi S1, Kelly CM, Cerchar E, Torabi B, Alekseev O, Fridman A, Friedman G, Azizkhan-Clifford J. Effects of non-thermal plasma on mammalian cells. PLoS One. 2011;6:e16270-81.

18. Golkowski M, Golkowski C, Leszczynski J, Plimpton SR, Maslowski P, Foltynowicz A, Jun Ye, McCollister B. Hydrogen-peroxide-enhanced nonthermal plasma effluent for biomedical applications. IEEE Trans Plasma Sci. 2012;40:1984-91. 
19. Kantari C, Pederzoli-Ribeil M, Witko-Sarsat V. The role of neutrophils and monocytes in innate immunity. Trends Innate Immunol. 2008;15:118-46.

20. Gertner J, Scotet E, Poupot M, Bonneville M, Fournié JJ. Lymphocytes: gamma delta. In: eLS. Chichester (UK): John Wiley \& Sons Ltd, Chichester; 2007. doi:10.1002/9780470015902. a0001195.pub2.

21. Fillatreau S, Gray D, Anderton SM. Not always the bad guys: B cells as regulators of autoimmune pathology. Nat Rev Immunol. 2008;8:391-7.

22. Kramer A, Bekeschus S, Bröker B, Schleibinger H, Razavi B, Assadian O. Maintaining health by balancing microbial exposure and prevention of infection: the hygiene hypothesis versus the hypothesis of early immune challenge. J Hospital Infection. 2013;83:29-34.

23. Bekeschus S, Masur K, Kolata J, Wende K, Schmidt A, Bundscherer L, Barton A, Kramer A, Bröker B, Weltmann K-D. Human mononuclear cell survival and proliferation is modulated by cold atmospheric plasma jet. Plasma Processes Polym. 2013;10:706-13.

24. Weltmann KD, Kindel E, Brandenburg R, Meyer C, Bussiahn R, Wilke C, von Woedtke T. Atmospheric pressure plasma jet for medical therapy: plasma parameters and risk estimation. Contrib Plasma Phys. 2009;49:631-40.

25. Kramer A, Lademann J, Bender C, Sckell A, Hartmann B, Münch S, Hinz P, Ekkernkamp A, Matthes R, Koban I, Partecke I, Heidecke CD, Masur K, Reuter S, Weltmann KD, Koch $\mathrm{S}$, Assadian O. Suitability of tissue tolerable plasmas (TTP) for the management of chronic wounds. Clin Plasma Med. 2013;1:11-8.

26. Nucera S, Biziato D, De Palma M. The interplay between macrophages and angiogenesis in development, tissue injury and regeneration. Int J Dev Biol. 2011;55:495-503.

27. Schneider DF1, Palmer JL, Tulley JM, Speicher JT, Kovacs EJ, Gamelli RL, Faunce DE. A novel role for NKT cells in cutaneous wound repair. J Surgical Res. 2011;168:325-33.

28. Korn T, Bettelli E, Oukka M, Kuchroo VK. IL-17 and Th17 cells. Ann Rev Immunol. 2009;27:485-517.

29. Jameson JM, Sharp LL, Witherden DA, Havran WL. Regulation of skin cell homeostasis by gamma delta T cells. Front Biosci. 2004;9:2640-51.

30. Warren HS, Smyth MJ. NK cells and apoptosis. Immunol Cell Biol. 1999;77:64-75.

31. Buttke TM, Sandstrom PA. Oxidative stress as a mediator of apoptosis. Immunol Today. 1994;15:7-10.

32. Krueger GG1, Langley RG, Leonardi C, Yeilding N, Guzzo C, Wang Y, Dooley LT, Lebwohl M; CNTO 1275 Psoriasis Study Group. A human interleukin-12/23 monoclonal antibody for the treatment of psoriasis. N Eng J Med. 2007;356:580-92.

33. Haertel B, Volkmanna F, Woedtke TV, Lindequist U. Differential sensitivity of lymphocyte subpopulations to non-thermal atmospheric-pressure plasma. Immunobiology. 2012;217:628-33.

34. Engelhardt E, Toksoy A, Goebeler M, Debus S, Bröcker E-B, Gillitzer R. Chemokines IL-8, GRO $\alpha$, MCP-1, IP-10, and Mig are sequentially and differentially expressed during phase-specific infiltration of leukocyte subsets in human wound healing. Am J Pathol. 1998;153:1849-60.

35. Janossy G, Greaves M. Lymphocyte activation: I. Response of T and B lymphocytes to phytomitogens. Clin Exp Immunol. 1971;9:483-93.

36. Remans PH1, van Oosterhout M, Smeets TJ, Sanders M, Frederiks WM, Reedquist KA, Tak PP, Breedveld FC, van Laar JM. Intracellular free radical production in synovial T lymphocytes from patients with rheumatoid arthritis. Arthritis Rheum. 2005;52:2003-9. 
37. Reddy M, Eirikis E, Davis C, Davis HM, Prabhakar U. Comparative analysis of lymphocyte activation marker expression and cytokine secretion profile in stimulated human peripheral blood mononuclear cell cultures: an in vitro model to monitor cellular immune function. $\mathrm{J}$ Immunol Methods. 2004;293:127-42.

38. Akbar AN1, Borthwick NJ, Wickremasinghe RG, Panayoitidis P, Pilling D, Bofill M, Krajewski S, Reed JC, Salmon M. Interleukin-2 receptor common $\gamma$-chain signaling cytokines regulate activated $\mathrm{T}$ cell apoptosis in response to growth factor withdrawal: Selective induction of anti-apoptotic (bcl-2, bcl-xL) but not pro-apoptotic (bax, bcl-xS) gene expression. Eur J Immunol. 1996;26:294-9.

39. Mosmann TR, Coffman RL. TH1 and TH2 cells: different patterns of lymphokine secretion lead to different functional properties. Ann Rev Immunol. 1989;7:145-73.

40. Fonseca AM, Porto G, Uchida K, Arosa FA. Red blood cells inhibit activation-induced cell death and oxidative stress in human peripheral blood $\mathrm{T}$ lymphocytes. Blood. 2001;97:3152-60.

41. Bundscherer L1, Wende K, Ottmüller K, Barton A, Schmidt A, Bekeschus S, Hasse S, Weltmann KD, Masur K, Lindequist U. Impact of non-thermal plasma treatment on MAPK signaling pathways of human immune cell lines. Immunobiology. 2013;218:1248-55.

42. Schütt C, Schilling T, Krüger C. sCD14 prevents endotoxin inducible oxidative burst response of human monocytes. Allerg Immunol. 1991;37:159-64. 
